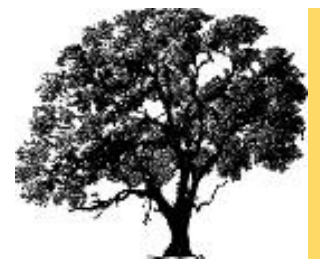

Eurasian Journal of Forest Science

2021 9(3): 246-258

http://dergipark.org.tr/en/pub/ejejfs

\title{
Kütahya merkez ilçe orman köylerinde ORKÖY tarafından verilen kredilerin (2000-2019) uygulama sonuçlarının incelenmesi
}

\author{
İbrahim ÇİRAY ${ }^{\mathrm{a}}$ (D) Hasan Emre ÜNAL ${ }^{\mathrm{b}}$ (D) \\ T.C. Orman Genel Müdürlüğü, Kütahya Orman Bölge Müdürlüğü \\ Çankırı Karatekin Üniversitesi, Orman Fakültesi, Orman Ekonomisi Anabilim Dalı, 18200, Çankırı
}

\begin{abstract}
Sorumlu yazar: hemre@karatekin.edu.tr
Özet

Bu çalışmada, Kütahya ili merkez ilçesi sınırları içerisinde yer alan orman köylerinde 2000-2019 yılları arasındaki 10 yıllık dönemde ORKÖY tarafindan gerçekleştirilen sosyo-ekonomik nitelikli kalkınma projelerinin uygulama sonuçlarının değerlendirilmesi amaçlanmıştır. Bu kapsamda, Merkez İşletme Şefliği, Çöğürler işletme Şefliği, Sabuncupınar İşletme Şefliği, Gümüşdağı İşletme Şefliği sınırları içinde ORKÖY'ün sağlamış olduğu kredilerden faydalanan toplam 32 adet orman köyünde 179 katılımcı ile yüz yüze anket yöntemi ve derinlemesine görüşme yöntemleri kullanılarak görüşmeler yapılmıştır. Elde edilen verilerin değerlendirilmesinde, frekans ve yüzde dağılımları, khi-kare bağımsızlık testi kullanılmıştır. İlişkilerin düzeylerini belirlemek için ise Cramer's V ve Gamma ilişki katsayıları kullanılmıştır. Buna göre, katılımcıların \%73'ünün temel geçim kaynağı tarımhayvancılıktır. Pek çok kırsal kesim yerleşim yerindeki yaşlı nüfusun aksine katılımcıların yaş ortalaması 51 'dir. Katılımcıların \%97.8'i hanede orman işleriyle uğraşan olmadığını, \%87.2'si orman teşkilatıyla ilişkilerin iyi olduğunu belirtmiştir. Katılımcıların \%43.6'sı ORKÖY faaliyetlerinden kısmen memnun olduklarını, \%44.7'si de herhangi bir fikir sahibi olmadığını ifade etmiş̦tir. Buna karşıllık katılımcıların \%94'ü belirtilen dönemde ORKÖY tarafından gerçekleştirilen süt/besi/güneş enerjisi projelerinin seçiminin doğru olduğunu belirtmiştir.
\end{abstract}

Anahtar Kelimeler: Orman, orman köylüsü, kırsal kalkınma, ORKÖY

Analysis of the Application Results of the Loans Given by ORKÖY in Kütahya Central District Forest Villages (2000-2019)

Abstract

In this study, it is aimed to evaluate the implementation results of the socio-economic development projects carried out by ORKÖY in the 10 year period between 2000-2019 in the forest villages located within the borders of the central district of Kütahya. In this context, interviews were made with 179 participants in a total of 32 forest villages benefiting from the credits provided by ORKÖY within the borders of the Central Sub-district Directorate, Çöğ̈̈rler Sub-district Directorate, Sabuncupınar Sub-district Directorate and Gümüşdağı Sub-district Directorate, using face-to-face survey method and in-depth interview methods. Frequency and percentage distributions, chisquare independence test were used to evaluate the obtained data. Cramer's V and Gamma correlation coefficients were also used to determine the levels of correlations. Accordingly, the main livelihood of $73 \%$ participant is agriculture-animal husbandry. Unlike the elderly population in many rural settlements, the average age of the participants is $51.97 .8 \%$ of the participants stated that the household is not dealing with forest works, $87.2 \%$ of them stated that the relations with the forest organization are good. While $43.6 \%$ of the participants stated that they were partially satisfied from ORKOY activities, $44.7 \%$ of them stated that they did not have any idea. On the other hand, $94 \%$ of the participants pointed out that the selection of milk / fattening / solar energy projects realized by ORKOY in the specified period was correct.

Key words: Forest, forest villager, rural development, ORKOY 


\section{GİRIŞ}

Kalkınma maddi refahın arttırılması yoksulluğun tamamen ortadan kalkması ve üretimdeki girdi ve çıktıların kompozisyonunun değiştirilmesi süreçlerini içermektedir. Toplumun var olan hayat standardının korunması ya da yükseltilmesi için daha etkin ve farklılaştıılmış metotlarla üretimde bulunmaya yönelik bir hareketin olmasıdır. Yani kalkınma aslında sadece ekonomik verilerle anlatılan bir kavram değil aynı zamanda sosyal yönü de kuvvetli olan bir kavramdır (Berber 2006). İlk kez Birleşmiş Milletler Örgütünce tanımı yapılan toplum kalkınması, kırsal kalkınma olarak da kabul edilmektedir. Farklı yönleriyle öne çıkarılarak birçok tanımı yapılan kırsal kalkınma; kırsal alanların doğal, sosyoekonomik ve alt yapıdan kaynaklanan dezavantajlarını ortadan kaldırma ve öncelikle bu alanlardaki kaynakları akılcı kullanarak kırsal refahı arttırma çabasıdır (Toksoy ve Bayramoğlu 2017).

Ormanlar, yerel insanlara geçimleri için gelir ve istihdam sağlayan, karakteristik olarak diğer yerlerden farklı bir doğal görüntü yaratan, kültürel ve tarihi değerleri bakımından, suyun, havanın ve toprağın korunması açısından ve yerel bölgelerin çekiciliğinin geliştirilmesi açısından önemli bir kaynaktır (Elands ve ark. 2004, Vedeld ve ark. 2007). Sosyo-ekonomik ve kültürel yaşamları ormanlarla sıkı bir şekilde ilişkili olan milyonlarca orman köylüsü geçimlerini ormanlardan sağlarken bu insanların ormanlara olan bağımlılığı bölgeden bölgeye değişmektedir. Orman köylüleri ormanları geçimlerini sağlamak, hayvan yetiştirmek, yakacak odun toplamak ve pazarda satacakları malların kaynağı olarak kullanmaktadırlar (Akhter ve ark. 2009).

22.3 milyon hektarlık orman varlı̆̆ ile Türkiye'de ormanların içinde veya bitişiğinde yer alan 22847 orman köyünde yaşayan 6.8 milyon orman köylüsü ve ormanlar birbirleriyle bütünlük ve çok yönlü etkileşim içindedir. Alan, servet, artım ve diğer nitelikleri belli ve sınırlı olan orman varlı̆̆ ile hayat seviyesi toplumun en gerisinde bulunan orman köylülerinin çeşitli sorunları bulunmaktadır (İnce ve Tolunay 2009). Göç sorunu orman köylerinde nüfusun her geçen gün azalmasına dolayısıyla da ormanları ve ormancılık faaliyetlerini yapacak kişilerin bulunmamasına neden olmaktadır. Orman köylerindeki nüfusun büyük çoğunluğunu kadın, çocuk ve yaşl1lar oluşturmaktadır (Eker ve Nazik, 2017). Ayrıca altyapı, sağlık, eğitim olanakları bakımından toplumun diğer kesimleri ile karşılaştırıldığında, bu köylerin daha düşük ve yetersiz durumda olduğu görülmektedir (Ekizoğlu vd., 2010). Orman köylerinde yaşayan insanların büyük kısmının tarıma elverişli olmayan topraklarda yaşadığı bilinmektedir. Orman köylerinde çalışmaya elverişli olan nüfusa iş olanaklarının olmayışı ya da az oluşu bu nüfusun ormanlar üzerindeki sosyal baskısını arttırmaktadır (Eker ve Nazik, 2017). Tablo 1'de 1960-2018 yılları arasında 10'ar yıllık dönemlere ait ülke nüfus, kırsal nüfus, orman köyleri nüfusları ve orman köyü sayılarına ait bilgiler verilmektedir.

Tablo 1.Yıllara göre orman köyü sayısı ve nüfusu (; Solmaz 2007; TUİK 2013; Türkiye Ormancılar Derneği 2019)

\begin{tabular}{ccccc}
\hline Yillar & Ülke Nüfusu & Kirsal nüfus & $\begin{array}{c}\text { Orman Köyü } \\
\text { Nüfusu }\end{array}$ & Orman Köyü Sayıs1 \\
1960 & 27754820 & 18895089 & 6658000 & 13252 \\
1970 & 35605176 & 21914075 & 7954071 & 15923 \\
1980 & 44736957 & 25091950 & 10161151 & 17568 \\
1990 & 56473035 & 23146684 & 8848501 & 17940 \\
2000 & 67823.927 & 23735567 & 7707588 & 20292 \\
2010 & 73.722988 & 17500632 & 7073000 & 21278 \\
2013 & 76667864 & $6 \mathbf{6 6 3 4 5 1 ^ { * }}$ & 7584000 & 21556 \\
2018 & 82003882 & 6003717 & 6827500 & 22847 \\
\hline
\end{tabular}

*2012 yılında çıkan 6360 sayılı Büyükşehir Kanunu ile 14 ilde büyükşehir belediyesi kurulmuş ve büyükşehir statüsündeki 30 ilde, belde ve köylerin ilçe belediyelerine mahalle olarak bağlanmıştır. 
1960 yılında Türkiye nüfusunun yaklaş1k \%23.9'unu orman köylüsü oluşturuyorken 2018 yılı itibari ile bu oran \%8.32'ye gerilemiştir. 1970-1980 yılları arasında orman köyü nüfusu artmıştır ancak 1980 yılından sonra Türkiye'de özellikle iç göçlerde meydana gelen artışlardan dolayı orman köyü nüfusu da azalma yaşamıştır. Yı1lara göre orman köyü sayısı ve nüfusundaki değişimler Şekil 1'de gösterilmiştir.

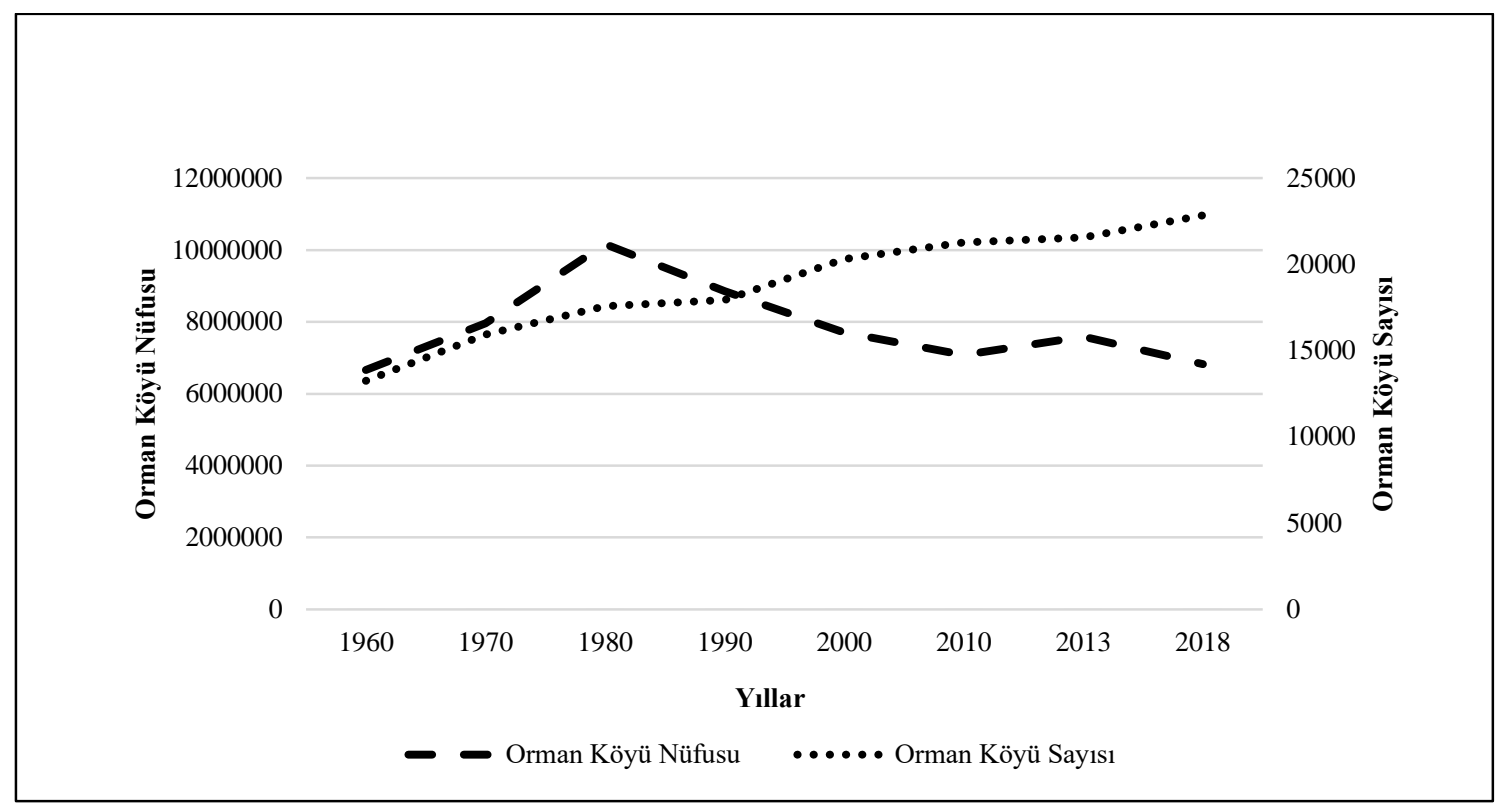

Şekil 1.Yıılara göre orman köyü sayısı ve nüfusundaki değiş̧im

Orman köylerinin diğer köylere göre daha dezavantajlı durumda olmasına neden olan bu nedenlerin ortadan kaldırılması için geçmişten günümüze çeşitli yasal ve planlı çalışmalar yapılmıştır (Daşdemir 2002). Ormanlar ve köylüler arasındaki ilişkiler ile ilgili çıkarılan yasalar yanında ORKÖY Genel Müdürlüğü, 1970 yılında Orman Bakanlığı'na bağlı olarak kurulmuştur. ORKÖY’ün öncelikli amacı ormanların korunması, geliştirilmesi, genişletilmesi ve işletilmesi hedeflerine ulaşırken, orman içi ve bitişiğinde yaşayan orman köylülerinin de sosyo-ekonomik ve kültürel açıdan gelişmelerini sağlamak ve bu şekilde ormanlar üzerindeki olumsuz baskıların azaltılmasıdır (ORKÖY 2002).

Bu çalışma ile Kütahya ili merkez ilçe orman işletme şeflikleri sınırları içinde yer alan orman köylerine yönelik belli bir dönem için seçilen ORKÖY kredilerinin başarı durumlarının değerlendirilmesi amaçlanmıştır.

\section{MATERYAL VE YÖNTEM}

Çalışmada materyal olarak, kurum kaynakları ve kurum yöneticileriyle yapılan görüşmeler ile belirlenen orman köylerinde muhtarlar ve köylerde yaşayan insanlarla yapılan anketler ve mülakatlar kullanılmıştır. Çalışmada elde edilen kayıtsal verilerin kaynak tarama yöntemiyle, çalışmaya katılan katılımcıların görüşlerinin yansıtılmasına yönelik veriler ise; a-Yüz yüze anket yöntemi, bDerinlemesine görüşme teknikleri ile elde edilmiştir. İsim ve nüfus bilgileri verilen köylerde son 10 yılda ORKÖY tarafindan sağlanan kredilerden faydalanan kişi sayısı ve faydalandıkları projeleri gösteren veriler aşağıda verilmiştir. 
Tablo 2. 2010-2019 döneminde ORKÖY kredi sayıları ve çeşitleri

\begin{tabular}{|c|c|c|c|}
\hline \multicolumn{4}{|l|}{ Merkez işletme şefliği } \\
\hline Köy adı & Kredi türü & Yıl & Faydalanan kiși sayısı \\
\hline Ortaca & Güneş enerjisi & 2010 & 18 \\
\hline Karsak & Süt sığırcılığı & 2011 & 5 \\
\hline Karsak & Süt sığırcıllı̆ı & 2012 & 4 \\
\hline Kıranşeyh & Süt sığırıcılığı & 2012 & 5 \\
\hline Sünnetyenice & Besi sığırcıllığ & 2013 & 5 \\
\hline İshakçılar & Besi sığırcıllı̆̆ & 2013 & 5 \\
\hline Kıranşeyh & Süt sığırcılığ & 2014 & 5 \\
\hline Körpe & Besi sığırcıllığ & 2015 & 3 \\
\hline Arslanlı & Süt sığırcılığı & 2016 & 3 \\
\hline Darica & Süt sığırcılığı & 2016 & 3 \\
\hline Kınık & Süt sığırcıllğı & 2017 & 5 \\
\hline Eynegazi & Süt sığııcıllı̆ı & 2017 & 5 \\
\hline Suluköy & Süt sığırcılığı & 2019 & 10 \\
\hline \multicolumn{4}{|l|}{ Çöğürler işletme şefliği } \\
\hline Göçebe & Süt sığırcılığı & 2012 & 5 \\
\hline Tepeköy & Süt sığırcılığı & 2013 & 8 \\
\hline Tepeköy & Besi sığırcıllı̆̆1 & 2013 & 10 \\
\hline Akoluk & Süt sığırcılığ & 2014 & 5 \\
\hline Yenice & Süt sığırrcılığı & 2014 & 5 \\
\hline Çöğürler & Süt sığırccilı̆̆ı & 2014 & 5 \\
\hline Gedikoğlu çiftliği & Süt sığırccilığı & 2015 & 5 \\
\hline Doğaarslan & Besi sığırcullı̆ 1 & 2016 & 5 \\
\hline Elmalı & Süt sığırcılığ 1 & 2017 & 5 \\
\hline Kızılcaören & Süt sığırcılığı & 2019 & 5 \\
\hline \multicolumn{4}{|c|}{ Sabuncupınar işletme şefliği } \\
\hline İnli & Güneş enerjisi & 2010 & 12 \\
\hline Bayramşah & Güneş enerjisi & 2010 & 8 \\
\hline Doğuluşah & Güneş enerjisi & 2010 & 17 \\
\hline Uluköy & Güneş enerjisi & 2010 & 48 \\
\hline Karacaören & Süt sığırcılığ 1 & 2011 & 6 \\
\hline İ̀nli & Süt sığırcılığı & 2013 & 7 \\
\hline Yeni Kızılcaören & Süt sığırcılığı & 2014 & 5 \\
\hline Sobran & Süt sığırcılığı & 2015 & 7 \\
\hline Sabuncupinar & Süt sığırçlığı & 2015 & 5 \\
\hline Hamidiye Kızılcaören & Süt sığırcılığı & 2019 & 5 \\
\hline \multicolumn{4}{|c|}{ Gümüşdağı işletme şefliği (Yeni şeflik) } \\
\hline Kirazlıyayla & Süt sığırcıllı̆̆ & 2018 & 4 \\
\hline \multirow[t]{2}{*}{ Karaağaç } & Süt sığırcilığı & 2019 & 4 \\
\hline & & & 262 kişi \\
\hline
\end{tabular}

Çalışma literatür ve alan araştırmalarına dayalı olarak gerçekleştirilmiştir. Literatür taraması sırasında konu ile ilgili daha önce yapılmış çalışmalar yanında kurumlardan elde edilen verilere yer verilmiştir. Alan araştırmasında ise, köylerle ilgili muhtarlar ile yapılan görüşmeler, araştırma konusunu oluşturan şefliklerde yer alan köylerde ORKÖY kredilerinden faydalanan hanelere yönelik soru kâğıtlarının hazırlanması ve değerlendirmeye alınması aşamaları izlenmiştir. Katılımcı değerlendirme formunda hane reislerine ait demografik (cinsiyet, yaş, eğitim, medeni hal, ortalama yıllık geliri hanehalkı büyüklüğü) soruların yanında hanenin ekonomik yapısı (temel geçim faaliyeti, tarım arazisi sahipliği, küçükbaş/büyükbaş hayvan sahipliği, kooperatif üyeliği) ve ormanla ve orman teşkilatıyla olan ilişkilerini ortaya koyacak sorulara yer verilmiştir. 
Görüşme yapılacak kişi sayısı (n) aşağıdaki formüle göre hesaplanmıştır (Baş, 2008);

$$
n=\frac{N x t^{2} x P x Q}{(N-1) d^{2}+\left(t^{2} x P x Q\right)}
$$

Formülde;

$N=$ birim say1s 1

$P=$ ölçülmek istenen özelliğin tahmini oranı

$Q=1-\mathrm{P}$

$t=\% 95$ güven düzeyi (1.96)

$d=$ hata pay1 (0.05)

Yapılan hesaplamaya göre; \%95 güvenilirlik aralığında, merkez ilçesi sınırları içinde 2010-2019 yılları arasında ORKÖY kredilerden faydalanmış olan 32 adet orman köyünde, süt sığırcılığı kredisinden faydalanan 66 kişi, besi sığırcıllğı kredisinden faydalanan 24 kişi ve güneş enerjisi kredisi alan 59 kişi olmak üzere toplam 149 kişi ile anket yapılması planlanmıştır. Besi sığırcılı̆̆ kredisinden yararlanan toplam 28 kişiden 24'üne ve güneş enerjisi kredisinden yararlanan toplam 103 kişiden 51 kişiye ulaşılma firsatı olmuştur. Süt sığırcılığı kredisinden faydalananlarla yapılması gerekli minimum anket sayısı 66 kişi olarak belirlenmesine karşın ulaşılabilen kişi sayısının artmasıyla birlikte eksik ve hatalı anket formları olabileceği düşünülerek ve daha güvenilir sonuçlar elde etmek için bu sayı 105 kişiye ulaşmıştır. Böylece toplamda 179 kişi ile anket yapılmıştır.

Çalışma sonucunda elde edilen verileri istatistiki açıdan değerlendirmek için SPSS 16.0 (Statistical Package for Social Sicence) paket programından faydalanılmıştır. Anket çalışmalarından elde edilen veriler, frekans ve yüzde tabloları halinde sunulmuştur. Ayrıca ki-kare bağımsızlık testi ile aralarında istatistiksel olarak anlamlı bir ilişki olan/olmayan değişkenlere yönelik değerlendirmeler yapılmıştır. Aralarında istatistiksel olarak anlamlı ilişki bulunan değişkenler arasındaki ilişkinin gücünü belirlemek için ise Phi ve Cramer's V ile Lamda ve Gamma ilişki katsayılarından yararlanılmıştır.

Tablo 3.Phi ve Cramer'in V katsayıları için ilişkigücü

\begin{tabular}{lc}
\hline Phi ve Cramer'in V si & Yorumlama \\
\hline$>0.25$ & Çok güçlü \\
$>0.15$ & Güçlü \\
$>0.10$ & Orta \\
$>0.05$ & Zayıf \\
$>0$ & Hiç yok/çok zayıf \\
\hline
\end{tabular}

Tablo 4. Lambda ve Gamma katsayıları için ilişki gücü

\begin{tabular}{lc}
\hline Lambda ve Gamma Katsayısı & Yorumlama \\
\hline \pm 1.00 & Çok güçlü \\
$\pm 0.30-0.99$ & Güçlü \\
$\pm 0.10-0.29$ & Orta \\
$\pm 0.01-0.09$ & Zayıf \\
0.00 & Hiç yok/çok zayıf \\
\hline
\end{tabular}

\section{BULGULAR}

\section{Demografik bilgiler}

Çalışmanın bu alt başlığında Tablo 5'te hane reislerine ait demografik özellikler özetlenmiştir. 
Tablo 5.Hane reislerine ait demografik özellikler

\begin{tabular}{|c|c|c|c|c|}
\hline Değişkenler & Öğeler & $\begin{array}{c}\text { Ortalama } \\
\text { (Standart sapma) }\end{array}$ & $\%$ & $\mathrm{n}$ \\
\hline \multirow[t]{2}{*}{ Cinsiyet } & Erkek & & 98.3 & 176 \\
\hline & Kadın & & 1.7 & 3 \\
\hline Yaş & & $51.16(11.203)$ & & \\
\hline \multirow[t]{6}{*}{ Eğitim } & Okuryazar değil & & 11.2 & 20 \\
\hline & $\begin{array}{l}\text { Okuryazar ama okul } \\
\text { bitirmemiş }\end{array}$ & & 4.5 & 8 \\
\hline & İlkokul & & 59.2 & 106 \\
\hline & Ortaokul & & 18.4 & 33 \\
\hline & Lise & & 6.1 & 11 \\
\hline & Lisans & & 0.6 & 1 \\
\hline \multirow[t]{3}{*}{ Medeni hal } & Bekâr & & 1.7 & 3 \\
\hline & Evli & & 93.3 & 167 \\
\hline & Dul & & 5.0 & 9 \\
\hline Ortalama yıllık gelir & & $\begin{array}{c}36625.70 \mathrm{TL} \\
(13204.511)\end{array}$ & & \\
\hline \multirow[t]{4}{*}{ Y1llık gelir düzeyleri } & $20000-30000 \mathrm{TL}$ & & 50.3 & 90 \\
\hline & $31000-50000 \mathrm{TL}$ & & 38.5 & 69 \\
\hline & $51000-70000 \mathrm{TL}$ & & 7.8 & 14 \\
\hline & $71000-100000 \mathrm{TL}$ & & 3.3 & 6 \\
\hline Hanehalkı büyüklüğü & & $3.37(1.600)$ & & \\
\hline
\end{tabular}

n: Örneklem alt küme

Tablo 5 incelendiğinde ankete katılan hane reislerinin neredeyse tamamına yakını (\%98) erkektir. Hane reisleri yaş ortalaması ise 51 olarak hesaplanmıştır. Dünya Sağl1k Örgütü'nün güncellemiş olduğu yaş aralıklarına göre (0-17 yaş: ergen; $18-65$ yaş: genç; 66-79 yaş: orta yaş ve 80-99 yaş: yaşl1) çalışamaya katılan hane reislerinin yaş ortalaması açısından genç sayılabilecek yaşa aralığında olduğu görülmektedir. Hane reislerinin büyük kısmı (\%77.6) ilköğretim düzeyinde bir eğitime sahiptir. Buna karş11ık herhangi düzeyde bir okul bitirme durumu olmayanların oranı ise \%15.7'dir. Yine ankete katılan hane reislerinin medeni durumlarına bakıldığında, \%93.3'ünün evli olduğu, buna karşıllk yalnızca \%1.7'lik bir kesimin bekâr olduğu görülmektedir. Hane reislerine sorulan y1llık ortalama gelir sorusuna verilen cevaplar neticesinde yapılan hesaplamaya göre, ortalama yıllık hane reisi geliri $36.625 \mathrm{TL}$ düzeyindedir. Çalışmaya konu olan köylerdeki ortalama hane büyüklüğü değeri ise 3.37 olarak hesaplanmıştır.

\section{Ekonomik yapı ve ormanla ilişki}

Çalışmanın bu başlı̆̆ altında katılımcıların temel geçim faaliyetleri, tarım arazisi sahipliği, küçükbaş/büyükbaş hayvan sahipliği, kooperatif üyeliği, ormanla ve teşkilatla ilişki ile ORKÖY faaliyetleriyle ilgili sorulan sorulara katılımcıların vermiş olduğu cevapların frekans ve yüzdesel dağılımlarını gösteren şekillere yer verilmiştir.

Tablo 6. Temel geçim faaliyeti

\begin{tabular}{llc}
\hline Temel Geçim Faaliyeti & Frekans & Yüzde (\%) \\
\hline Tarım & 15 & 8.4 \\
Hayvancılık & 25 & 14 \\
Tarım-Hayvancılık & 131 & 73.2 \\
Tarım-Hayvancılık-Ormancılık & 4 & 2.2 \\
Diğer & 4 & 2.2 \\
\hline
\end{tabular}


Tablo 6'ya göre, katılımcıların \%73.2'si (131 kişi) temel geçim faaliyetlerinin tarım ve hayvancılık üzerine olduğunu ifade etmiştir. Temel geçim faaliyeti olarak sadece hayvancılık diyenlerin oranı $\% 14$ (25 kişi) ve sadece tarımsal faaliyetlerle geçimlerini sağlayanların oranı ise \%8.4’tür (15 kişi).

Tablo 7. Haneye ait tarım arazisi

\begin{tabular}{lcc}
\hline Tarım arazisi & Frekans & Yüzde (\%) \\
\hline Var & 152 & 84.9 \\
Yok & 27 & 15.1 \\
\hline
\end{tabular}

Tarım arazisi sahiplik durumunu gösteren Tablo 7'ye göre, katılımcıların \%84.9'u (152 kişi) tarım arazisine sahip olduğunu ifade etmiştir.

Tablo 8. Küçükbaş/Büyükbaş hayvan sahipliği

\begin{tabular}{lcc}
\hline Küçükbaş/Büyükbaş Hayvan & Frekans & Yüzde (\%) \\
\hline Var & 176 & 98.3 \\
Yok & 3 & 1.7 \\
\hline
\end{tabular}

Tablo 8'de verilen frekans ve oransal değerlere göre, katılımcı hane reislerinin \%98,3'ü (176 kişi) küçükbaş/büyükbaş hayvanı olduğunu söylemiştir. Hayvancılık çalışma alanındaki köyler için temel geçim kaynağı durumundadır. Çiftçiliğin de ekonomik bakımdan yetersiz olması hayvancılık faaliyetini ön plana çıkarmıştır.

Tablo 9. Kooperatif üyeliği

\begin{tabular}{lcc}
\hline Kooperatif üyeliği & Frekans & Yüzde (\%) \\
\hline Var & 61 & 34.1 \\
Yok & 118 & 65.9 \\
\hline
\end{tabular}

Tablo 9'da katılımcıların herhangi bir kooperatife üyelik durumlarını gösteren frekans ve yüzde değerlerine bakıldığında katılımcıların yarısından fazlasının \%65.9 (118 kişi) herhangi bir kooperatife üye olmadıkları görülmektedir. Kooperatife üye olduğunu belirtenlerin oranı \%34.1 (61 kişi) dir. Kooperatife üye olmama konusundaki temel sebep hayır cevabı verenlerin çoğunun bulunduğu yerleşim birimlerinde kooperatif kurulmamış olmasından kaynaklıdır. Köylerinde kooperatif olmasına rağmen üyelik durumu olmadığını belirtenlerin dile getirdiği en önemli sebeplerden biri kooperatifin kendilerine bir yarar sağlamayacağı düşüncesidir. Bunun yanında köylülerin yapılan kooperatif kesintilerini ödemek istememeleri, kooperatiflerden sağlanan yardımların fazlasıyla ve faiziyle geri istenmesi ile kooperatif yönetimiyle olan sorunlar da kooperatife üyeliği olumsuz yönde etkileyen faktörler olarak belirtilmiştir.

Tablo 10. Ormanın sağladı̆̆ı en önemli fayda

\begin{tabular}{lcc}
\hline En önemli orman faydası & Frekans & Yüzde (\%) \\
\hline Odun hammadde kaynağı & 65 & 35.8 \\
ODOÜ kaynağı & 2 & 1.1 \\
Estetik & 6 & 3.4 \\
Rekreasyonel kullanım & 14 & 7.8 \\
Temiz hava & 35 & 19.6 \\
Erozyon, sel vb. koruma & 1 & 0.6 \\
Hayvan otlatma & 57 & 31.8 \\
\hline
\end{tabular}

Tablo 10'a göre, katılımcıların ormanlara bakış açısını da ortaya koymuş olan ormanlardan sağlanan en önemli faydanın sorulduğu soruya vermiş oldukları cevaplara göre, katılımcıların \%35.8’i (64 kişi) en önemli fayda olarak ormanların odun hammaddesi kaynağı olmasını göstermiştir. Yakın bir oranla 
katılımcıların \%31.8'i (57 kişi) ise ormanların kendilerine hayvan otlatma açısından önemli bir fayda sağladığını ifade etmiştir.

Tablo 11. Hanede orman işiyle uğraşan mevcudiyeti

\begin{tabular}{lcc}
\hline Orman işiyle uğraşan & Frekans & Yüzde (\%) \\
\hline Var & 4 & 2.2 \\
Yok & 175 & 97.8 \\
\hline
\end{tabular}

Katılımcı hane reislerine hanede orman işleriyle uğraşanların olup/olmadığını öğrenmek için sorulan soruya verilen cevapların dağılımını gösteren Tablo 11'e göre, katılımcıların neredeyse tamamına yakın bir çoğunluk \%97.8 (175 kişi) herhangi bir orman işinde çalışmadığını belirtmiştir. Oturulan köylerin çoğunda ormanlık alan çok fazla olmamakla birlikte mevcut ormanlarında bozuk orman yapısında olmasından dolayı ormancılık işi fazla bulunmamaktadır. Katılımcılar ormancılık faaliyetlerinden elde ettikleri gelirin, sarf ettikleri emeği karşılamamasından yakınmaktadırlar. Üretim faaliyetleri için orman teşkilatının ödediği birim fiyatlar köylülerin ormancılık işlerinde çalışmaları için yeterli gelmemektedir. Çoğu köylünün emekli maaşının olması, çiftçilikten ve hayvancılıktan belirli bir kazanç elde etmeleri orman işlerini külfet olarak görmelerine neden olmaktadır. Bazı orman köylerinde ise adam eksikliğinden dolayı orman işleriyle uğraşılmamaktadır. Köylüler çiftçilikle ve hayvancılıkla zor uğraştıklarını orman işlerinde çalışmaya insan olmadığını belirtmişlerdir.

Tablo 12. Orman teşkilatıyla ilişki

\begin{tabular}{lcc}
\hline Orman teşkilatıyla ilişki & Frekans & Yüzde (\%) \\
\hline İyi & 156 & 87.2 \\
Orta & 15 & 8.4 \\
Kötü & 8 & 4.5 \\
\hline
\end{tabular}

Katılımcıların orman teşkilatıyla olan ilişkilerin durumunu ortaya konulmuştur. Tablo 12'ye göre, katılımcılar ile orman teşkilatı arasında iyi bir ilişki olduğu söylenebilir. Katılımcıların \%87.2'si (156 kişi) bu ilişkiyi iyi olarak nitelendirirken \%4.5'lik (8 kişi) bir kesim orman teşkilatıyla olan ilişkilerini kötü olarak belirtmiştir. Orman teşkilatıyla ilişkilerin çoğunlukla iyi olarak değerlendirilmesinin sebebi; ormandan çok fazla beklentilerinin olmaması ve bu yüzden fazla münasebet kurulmaması olarak belirtilmiştir. Ayrıca, Orman teşkilatından istenilen en önemli şey kışlık yakacak odunun karşılanmasıdır. Kışlık yakacak odunun karşılanması orman teşkilatıyla ilişkileri iyi olarak nitelendirmektedirler. Orman teşkilatıyla aranın iyi olarak nitelenmesinin bir sebebi de ORKÖY kredilerinin hibeli ve faizsiz olarak vadeye bölünerek geri alınmasından da kaynaklanmaktadır.

Tablo 13. ORKÖY faaliyetlerinin yeterliliği

\begin{tabular}{lcc}
\hline ORKÖY faaliyetleri & Frekans & Yüzde (\%) \\
\hline Evet & 8 & 4.5 \\
Kismen & 78 & 43.6 \\
Hayir & 13 & 7.3 \\
Fikrim yok & 80 & 44.7 \\
\hline
\end{tabular}

Tablo 13'e göre, katılımcı hane reislerinin yarısına yakını \%43.6 (78 kişi) ORKÖY faaliyetlerinin yeterli olup/olmadığıyla ilgili soruya kısmen cevabını verirken, yine yarısına yakın \%44.7 (80 kişi) si de fikrim yok cevabını vermiştir. Kredilerin kısmen yeterli olduğunu bildirenler genel olarak kredi miktarının fazla olmasını isteyenlerdir. Fikir beyan etmeyenler ise krediyi almış olup kullandıktan sonra olsa da olur olmasa da olur mantığıyla hareket edenler şeklinde ağırlıklıdır. ORKÖY faaliyetlerinin yeterli olduğunu düşünenlerin oranı ise yalnızca \%4.5 (8 kişi) dir.Alanda yapılan gözlemler neticesinde ve 
mevcut bilgilere dayanılarak şu tespitlere de yer verilebilir: Köylüler açısından ORKÖY kredilerinin katkısının olduğunu söyleyenler bu kredileri doğru şekilde kullanabilenlerdir. Memnuniyetsizlik dile getirenler ise; kredileri doğru şekilde kullanmayıp verilen kredilerle iş yapamayan ve bunu sonucunda geri ödeme zamanı geldiğinde borçlarını ödeyemeyip icra takibine düşenler yanında çalıştı̆̆ halde bu kredilerden faydalanmak isteyip faydalanma şansı verilmeyenler, bekar olduğu için yine bu kredi imkanlarından faydalanmayanlar şeklindedir. Kredilerin az bulunmasının bir sebebi özellikle hayvancılıkla ilgili verilen kredi miktarlarının düşük olması ve az hayvan alınabilmesidir. Köylüler kredi miktarlarının arttırılarak daha fazla hayvan almak istemektedirler. ORKÖY tarafından sağlanan desteklerin çoğu o yöre köylüsünün ihtiyaçları doğrultusunda verilmektedir. Verilen kredilerden köy nüfusuna kayıtlı o köyde ikamet eden (hane başına 1 kişi olacak şekilde) herkes yararlanabilmektedir.

\section{Khi-kare bağımsızlık analizi ve ilişki düzeyleri sonuçları}

Khi-kare bağımsızlık analizi sonuçlarına göre aralarında istatistiki olarak anlamlı ilişki olan değişkenler ve ilişki düzeylerine ilişkin değerlendirmeler Tablo 14 ve Tablo 15 'te verilmiştir.

Tablo 14. Ki-kare bağımsızlık testlerine ilişkin sonuçlar

\begin{tabular}{|c|c|c|c|}
\hline & Ki-kare değeri & Anlamlılık değeri & İlişki durumu \\
\hline $\begin{array}{l}\text { Göç etmeyi düşünme-orman köylüsü olma } \\
\text { memnuniyeti }\end{array}$ & - & $\begin{array}{c}\mathrm{P}=0.012 \\
\text { (fisher's exact test) }\end{array}$ & İlişki var \\
\hline Yaş grubu-temel geçim faaliyeti & $\chi_{\text {hesap }}^{2}: 46.303$ & $\mathrm{P}=0.000<0.05$ & İlişki var \\
\hline $\begin{array}{l}\text { Orman köylüsü olma memnuniyet-ormanın } \\
\text { sağladığ1 en önemli fayda }\end{array}$ & $\chi^{2}$ hesap: 16.090 & $\mathrm{P}=0.013<0.05$ & İlişki var \\
\hline $\begin{array}{l}\text { Orman köylüsü olma memnuniyet-doğal } \\
\text { kaynaklardan yeterince faydalanma }\end{array}$ & $\chi^{2}$ hesap: 14.325 & $\mathrm{P}=0.001<0.05$ & İlişki var \\
\hline $\begin{array}{l}\text { Orman teşkilatıyla ilişki - ORKÖY } \\
\text { çalışmalarının yeterli olması }\end{array}$ & $\chi^{2}$ hesap $: 15.576$ & $P=0,016<0.05$ & İlişki var \\
\hline $\begin{array}{l}\text { ORKÖY çalışmalarının yeterli olması- } \\
\text { ORKÖY projelerinin geliri artırma durumu }\end{array}$ & $\chi^{2}$ hesap:49.179 & $\mathrm{P}=0.000<0.05$ & İlişki var \\
\hline $\begin{array}{l}\text { ORKÖY desteğinde süt sığırcılığının gelişme } \\
\text { durumu-köy meralarının yeterliliği }\end{array}$ & - & $\begin{array}{c}\mathrm{P}=0.000 \\
\text { (fisher's exact test) }\end{array}$ & İlişki var \\
\hline $\begin{array}{l}\text { Ormanın sağladığı en önemli fayda- doğal } \\
\text { kaynaklardan yeterince faydalanma }\end{array}$ & $\chi^{2}$ hesap: 40.791 & $\mathrm{P}=0.022<0.05$ & İlişki var \\
\hline
\end{tabular}

Tablo 14'e göre; göç etmeyi düşünme-orman köylüsü olma memnuniyeti; yaş grubu-temel geçim faaliyeti; orman köylüsü olma memnuniyeti-ormanın sağladığı en önemli fayda; orman köylüsü olma memnuniyeti-doğal kaynaklardan yeterince faydalanma; orman teşkilatıyla ilişki - ORKÖY çalışmalarının yeterli olması; ORKÖY çalışmalarının yeterli olması-ORKÖY projelerinin geliri artırma durumu; ORKÖY desteğinde süt sığırcılı̆̆ının gelişme durumu-köy meralarının yeterliliği; ormanın sağladığı en önemli fayda-doğal kaynaklardan yeterince faydalanma sorularına verilen cevaplar arasında $\% 5$ önem düzeyi ile anlamlı ilişki belirlenmiştir $\left(\mathrm{P}=0.012 ; \chi^{2}\right.$ hesap: 46.303, $\mathrm{P}=0.000<0.05 ; \chi^{2}$ hesap: $16.090, \mathrm{P}=0.013<0.05 ; \chi^{2}$ hesap: $14.325, \mathrm{P}=0.001<0.05 ; \chi^{2}$ hesap: $15.576, \mathrm{P}=0,016<0.05 ; \chi^{2}$ hesap: 49.179, $\mathrm{P}=0.000<0.05 ; \mathrm{P}=0.000 ; \chi^{2}$ hesap: 40.791, $\left.\mathrm{P}=0.022<0.05\right)$.

Aralarında anlamlı ilişki tespit edilen sorulara verilen cevapların ilişki düzeylerinin sunulduğu Tablo 15'e göre; göç etmeyi düşünme-orman köylüsü olma memnuniyeti sorularına verilen cevaplar arasında ters yönlü ve çok güçlü $(\Phi=-0.259, \mathrm{P}<0.05)$; yaş grubu-temel geçim faaliyeti arasında çok güçlü $(\mathrm{V}=0.251, \mathrm{P}<0.05)$; orman köylüsü olma memnuniyeti-ormanın sağladığı en önemli fayda arasında çok güçlü $(\mathrm{V}=0.282, \mathrm{P}<0.05)$; orman köylüsü olma memnuniyeti-doğal kaynaklardan yeterince faydalanma arasında çok güçlü $(\mathrm{V}=0.271, \mathrm{P}<0.05)$; orman teşkilatıyla ilişki - ORKÖY çalışmalarının yeterli olması 
Tablo 15. Ki-kare bağımsızlık testleri sonuçlarına göre ilişki düzeyleri

\begin{tabular}{|c|c|c|c|}
\hline & Katsay1 & Anlamlılık değeri & İlişki düzeyi \\
\hline $\begin{array}{l}\text { Göç etmeyi düşünme-orman köylüsü olma } \\
\text { memnuniyet }\end{array}$ & $\Phi=-0.259$ & $\mathrm{P}<0.05$ & $\begin{array}{l}\text { Ters yönlü ve } \\
\text { çok güçlü }\end{array}$ \\
\hline Yaş grubu-temel geçim faaliyeti & $\mathrm{V}=0.251$ & $\mathrm{P}<0.05$ & Çok güçlü \\
\hline $\begin{array}{l}\text { Orman köylüsü olma memnuniyet-ormanın } \\
\text { sağladığı en önemli fayda }\end{array}$ & $\mathrm{V}=0.282$ & $\mathrm{P}<0.05$ & Çok güçlü \\
\hline $\begin{array}{l}\text { Orman köylüsü olma memnuniyet-doğal } \\
\text { kaynaklardan yeterince faydalanma }\end{array}$ & $\mathrm{V}=0.271$ & $\mathrm{P}<0.05$ & Çok güçlü \\
\hline $\begin{array}{l}\text { Orman teşkilatıyla ilişki - ORKÖY } \\
\text { çalışmalarının yeterli olması }\end{array}$ & $\gamma=-0.100$ & $\mathrm{P}<0.05$ & $\begin{array}{l}\text { Ters yönlü orta } \\
\text { düzey }\end{array}$ \\
\hline $\begin{array}{l}\text { ORKÖY çalışmalarının yeterli olması- } \\
\text { ORKÖY projelerinin geliri artırma durumu }\end{array}$ & $\mathrm{V}=0.503$ & $\mathrm{P}<0.05$ & Çok güçlü \\
\hline $\begin{array}{l}\text { ORKÖY desteğinde süt sığırcılığının gelişme } \\
\text { durumu-köy meralarının yeterliliği }\end{array}$ & $\Phi=0.592$ & $\mathrm{P}<0.05$ & Çok güçlü \\
\hline $\begin{array}{l}\text { Ormanın sağladığı en önemli fayda- doğal } \\
\text { kaynaklardan yeterince faydalanma }\end{array}$ & $\mathrm{V}=0.244$ & $\mathrm{P}<0.05$ & Güçlü \\
\hline
\end{tabular}

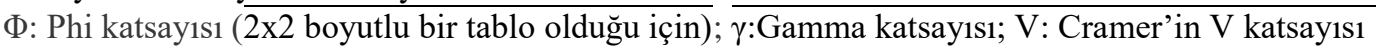

arasında ters yönlü ve orta düzey $(\gamma=-0.100, P<0.05)$; ORKÖY çalışmalarının yeterli olması-ORKÖY projelerinin geliri artırma durumu arasında çok güçlü $(\mathrm{V}=0.503, \mathrm{P}<0.05)$; ORKÖY desteğinde süt sığırcılığının gelişme durumu-köy meralarının yeterliliği arasında çok güçlü $(\Phi=0.592, \mathrm{P}<0.05)$; ormanın sağladığı en önemli fayda-doğal kaynaklardan yeterince faydalanma sorularına verilen cevaplar arasında güçlü $(\mathrm{V}=0.244, \mathrm{P}<0.05)$ ilişkiler belirlenmiştir.

\section{TARTIŞMA VE SONUÇ}

Temel geçim faaliyetleri konusunda benzer bulgulara ulaşan Usta (2020)' ye göre, Katılımcıların \%68'i tarım ve hayvanc1lıktan elde edilen ürünleri belirtirken, $\% 28$ 'ide ormanc1lık faaliyetlerinin geçim kaynağı olduğunu ifade etmiştir. Kılıç (2012) çalışmasında katılımcıların çoğunluğunun (\%56.6) çiftçilikle uğraştığını ifade etmiştir. Ancak ormancılık faaliyetlerinin de haneler arasında gelir kaynağı olarak görüldüğü belirtilmiştir. Soydan (2010) çalışmasında katılımcı orman köylülerinin \%89'unun tarımsal faaliyetlerle geçim sağladığını belirtmiştir. Bu tespitlerin aksi bir bulguya ulaşan Nazik (2017) ise çalışmasında katılımcıların \%54'ünün temel geçim kaynağının ormancılık faaliyetleri olduğunu belirtmiştir. Hayvancılı̆̆ın da ormancılık faaliyetleri dışında \%36'lık bir kesim tarafından temel geçim kaynağı olarak belirttiği de ifade edilmiştir. Benzer bir tespitte bulunan Özsan (2011), köylülerin temel geçim faaliyetlerinin \%40 ile ormancılık ve \%39 ile de hayvancılık olarak çeşitlendiğini belirtmiştir. Önal (2010) katılımcıların \%38'inin hayvanc1lık ve \%17'sinin de ormanc1lık faaliyetlerini temel geçim kaynağı olarak belirtmiştir. Uzun (2010) ise çalışmasında daha farklı bir tespitte bulunmuş ve temel geçim kaynağı olarak katılımcıların yarısından fazlasının (\%52) emeklilik maaşı ve işçilik ücreti (\%29) ile geçim sağladığını belirtmiştir. Yazar ayrıca tarım ve hayvancılık ve ormancılığın yan faaliyetler olarak geçim kaynağı olduğunu da ifade etmiştir.

Tarım arazisine sahip olma durumuyla ilgili olarak, Uzun (2010) katılımcıların \%98'inin tarım arazisine sahip olduğunu belirtmiştir. Buna karşılık, Nazik (2017)'nin çalışma bulgularından biri çalışma alanındaki köylerde tarım arazisinin yeterli olmadığı yönündeki tespiti olmuştur. Köylülerin kış mevsiminde köy dışında olmalarından dolayı da zaten mevcut arazileriyle de ilgilenemedikleri belirtilmiştir. Benzer şekilde Özsan (2011) çalışmasında katılımcıların \%50'sinin kendine ait arazisi olduğunu ve katılımcıların \%57'sinin de arazilerin yetersiz olduğu ve tarımsal faaaliyetle uğraşan köylülerin çoğunun arazi yapısındaki bozukluğun da etkisiyle sadece tüketim amaçlı tarımsal 
faaliyetlerle uğraştı̆̆ını ifade etmiştir. Önal (2010) ise çalışmasında katılımcıların \%90 dan fazlasının arazisi olduğunu ancak bu arazilerin kullanım şeklinin farklı olduğu tespitini yapmıştır.

Hayvan sahipliği konusunda çalışma bulgularıyla benzer bir tespit Nazik (2017) tarafından ortaya konmuştur. Buna göre, yazar çalışmasında katılımcıların \%80'ninin küçükbaş/büyükbaş hayvan sahibi olduğunu belirtmiştir. Özsan (2011) çalışmasında çalışma alanındaki halkın büyük çoğunluğunun küçükbaş/büyükbaş hayvancılık (küçükbaş ağırlıklı) ile uğraştığını belirtmiştir. Uzun (2010)'a göre katılımcıların \%50'si büyükbaş hayvan sahipliği olmadığını, \%96'sı da küçükbaş hayvan sahipliğinin söz konusu olmadığını ifade etmiştir.

Katılımcıların kooperatif üyeliği durumu ve bakış açılarına yönelik soruların sorulduğu çalışmalar da mevcuttur. Bu çalışmalardan biri olan Usta (2020) çalışmasına katılanların yarısının kooperatif üyesi olduğunu dile getirmiştir. Aynı çalışmada katılımcıların \%79'u da kooperatiflerin ekonomik açıdan köylülere olumlu bir etkisinin olmadığını belirtmiştir. Benzer şekilde Kılıç (2012) çalışma alanındaki köylerde kooperatifleşme olmadığını belirtmiştir. Bunun temel nedeni olarak ise köylülerin çok büyük çoğunluğunun (\%94) kooperatifleşmenin herhangi bir fayda sağlamayacağ 1 düşüncesinde olmaları gösterilmiştir.

Katılımcılara ormanların sağladığı en önemli faydayı tespit etmek adına soruya verilen cevaplarla elde edilen bulgulara yakın tespitlerde bulunan çalışmalardan birinde, Akçam (2019) çalışmasında katılımcıların ormanların en önemli işlevi olarak odun hammaddesi kaynağı olmasını (\%88) göstermiştir. Nazik (2017) ve Özsan (2011) çalışmalarında katılımcıların çoğunluğunun (\%40; \%42) ormandan en çok faydalanma şeklinin hayvan otlatma olduğunu tespit etmiştir. Bu bulguların aksine Kılıç (2012) ve Uzun (2010) çalışmalarında köylülerin ormanı öncelikli olarak iş imkânı olarak gördüklerini belirtmiştir. Benzer bir tespit yapan Önal (2010)'ın çalışmasında katılımcıların ormandan sağladığı öncelikli faydalar sırasıyla \%31 istihdam, \%27 hayvan otlatma ve \%25 ile de yapacak/yakacak odun temini şeklindedir.

Çalışmada hanesinde orman işiyle uğraşanların yok denecek kadar az olduğunun tespit edilmesine karş11ık Kılıç (2012)'ye göre, katılımcıların \%52'si ormancılık faaliyetlerinin kendileri için önemli bir gelir kaynağı olduğunu ifade etmiştir. Ancak aynı çalışmada ormancılık faaliyetleri için ödenen birim ücretlerin yeterli olmadığını belirtenlerin oranı \%77 olarak verilmiştir.

Orman teşkilatıyla katılımcı orman köylülerinin ilişkilerinin sorulduğu soruya verilen cevaplarla elde edilen bulgularla benzerlik gösteren Önal (2010), çalışmasında katılımcıların \%72'sinin teşkilatla olan ilişkilerinin iyi olduğunu belirtmiştir. K1lıç (2012)'ye göre katılımcıların \%95'inin teşkilatla ilişkilerin iyi olduğu tespit edilmiştir. Aynı çalışmada katılımcıların çoğunluğu korunan alanların artmasının kendilerini olumlu etkileyeceği yönünde (\%62) görüş bildirmiştir. Yazar bunun en önemli nedenlerinden biri olarak yörede henüz korunan alan mevcut olmayışı ve dolayısıyla da köylülerin orman kaynaklarından faydalanmalarında herhangi bir kısıtlamaya gidilmemiş olmasını göstermiştir. Nazik (2017) ise çalışmasında orman işletmesinin kendilerine yapacak ve yakacak odun temin ettiğini, parayla satın alma durumunda ise fiyatı pahalı bulduklarını dile getirmiştir. Yazar ayrıca çalışmasında orman işletmesinin orman köylülerinin yarısından fazlasına istihdam sağladığını da tespit etmiştir. Katılımcıların teşkilatla olan ilişkilerini irdeleyen bir başka çalışmada Özsan (2011)'de katılımcıların teşkilatla olan ilişkilerinde \%51'lik kesimin sorun yaşamadığını tespit etmiştir. 
Çalışmada ORKÖY faaliyetlerinin yeterliliği konusundaki tespitlerde katılımcıların \%43.6'sının kısmen cevabı verdiği buna yakın bir katılımcı yüzdesinin de fikir beyan etmek istemediği tespit edilmesine karş1lık farklı tespitlerde bulunan çeşitli çalışmalar da söz konusudur. Bunlardan Önal (2010) çalışmasında katılımcıların \%27'sinin ORKÖY kredilerinden memnun olduğunu ve \%15'inin de fikir beyan etmediklerini tespit etmiştir. Çalışmasında bu konuyla ilgili bulgulara ulaşan Soydan (2010)'da katılımcıların \%63'ünün ORKÖY faaliyetlerini yeterli bulduğunu belirtmiştir. Buna karş1lı bunun aksi bulgulara ulaşan çalışmalar da olmuştur. Kılıç (2012) çalışmasında katılımcıların \%92'sinin, Tonyalı (2019) ise katılımcıların \%53'ünün o zamana kadar herhangi bir ORKÖY kredisinden faydalanmadığını belirtmiştir. Yine Kılıç (2012)'göre, ORKÖY faaliyetlerinin yeterli düzeyde olup/olmadığını öğrenmek için sorulan soruya verilen cevaplarda katılımcıların \%92'si yetersiz olarak görüş bildirmiştir. Benzer bir tespitte bulunan Akçam (2019) çalışmasına katılanların yaklaşık \%70'inin ORKÖY tarafından gerçekleştirilen faaliyetlerin yetersiz olduğunu belirtmiştir.

Sonuç olarak; orman köylerinin sayısındaki artışa karşın orman köylüsü nüfusunda bir azalma olduğu görülmektedir. Bu durumun önüne geçebilmek adına ORKÖY tarafından hem sosyal hem ekonomik açıdan verilen kredilerin daha da genişlettirilerek ve geliştirilerek sunulması, orman köylerinde yaşamlarını sürdürmek durumunda olan insanların hayat kalitelerini artırmak suretiyle yerleşim yerlerinde kalmasını sağlamak bakımından önem arz etmektedir. ORKÖY projeleri ekonomik açıdan orman köylüleri için önemli bir unsurdur ve bu tür projelerin artırılarak devam ettirilmesi orman köylüleri tarafından da beklenmektedir.

\section{Açıklama}

$\mathrm{Bu}$ çalışma, Çankırı Karatekin Üniversitesi Fen Bilimleri Enstitüsü Orman Mühendisliği Anabilim Dalında hazırlanan "Kütahya İli Merkez İlçe Orman Köylerinde ORKÖY Uygulama Projelerinin Sonuçlarının Değerlendirilmesi” başlıklı yüksek lisans tez çalışmasından hazırlanmıştır.

\section{Kaynaklar}

Akçam, E. (2019). Orman köylerine verilen desteklerde etkili olan yerel aktörlerin sosyal ağ analizi ile belirlenmesi, Isparta Uygulamalı Bilimler Üniversitesi, Lisansüstü Eğitim Enstitüsü, Yüksek Lisans Tezi, Isparta, $65 \mathrm{~s}$

Akhter, S., Sohel, S.I., Rana,,P., Alamgir, M. (2009). Impact of forests and non-forests villagers on Ukhia and Inanı forest range under Cox's Bazar (South) Forest Division, Bangladesh, Proc. Pakistan Acad. Sci. 46(1):13-22.

Baş, T. (2008). Anket: anket nasıl hazırlanır?, anket nasıl uygulanır?, anket nasıl değerlendirilir? : Seçkin yayıncilık.

Berber, M. (2006). İktisadi büyüme ve kalkınma, Derya Kitapevi, Trabzon.

Daşdemir, İ. (2002). Sarıkamış ve Oltu yöresindeki ormancılık kooperatiflerinin kırsal kalkınma ve bölge ormancılığı açısından değerlendirilmesi, 1. Ulusal Ormancılık Kooperatifleri Bildiri Kitabı, Kastamonu, s.107128.

Eker, Ö. ve Nazik, S., (2017). Orman kaynaklarının yoksulluk yönetimi ve kırsal kalkınma üzerine sosyoekonomik etkileri: Kastamonu Pınarbaşı ilçesi örneği, Turkish Journal of Forest Science 1(1):44-58.

Ekizoğlu,A., Kuvan, Y., Özden, S., Erdönmez, C., (2010). Ormancılıkla ilgili diğer politikalar, Ormancılık politikası, Akesen, A. ve Ekizoğlu, A. (ed)., Türkiye Ormancılar Derneği, Yayın No:6, Ankara,s.147-213.

Elands, B.H.M., O’Leary, T. N., Boerwinkel, W.J., Wersum,,K.F. (2004). Forests as a mirror of rural conditions; local views on the role of forests across Europe, Forest Policy and Economics, (6), s.469-482. 
İnce, Y., Tolunay, A. (2009). Orman köylülerinin orman kaynaklarından yapacak odun yararlanma haklarının ekonomik boyutu (Isparta İli Orman Köyleri Örneği), II. Ormancılıkta Sosyo-Ekonomik Sorunlar Kongresi, Isparta, s.206-216.

Kılıç, M. (2012). Orman köylülerinin ormancılık etkinliklerine ilişkin algı ve beklentilerinin belirlenmesi (Sivas orman işletme müdürlüğü örneği), Süleyman Demirel Üniversitesi, Fen Bilimleri Enstitüsü, Yüksek Lisans Tezi, Isparta, $116 \mathrm{~s}$

Nazik, S. (2017). Orman kaynaklarinin yoksulluk yönetimi ve kirsal kalkınma üzerine sosyo - ekonomik etkileri, Kahramanmaraş Sütçü İmam Üniversitesi, Fen Bilimleri Enstitüsü, Yüksek Lisans Tezi, Kahramanmaraş, 99 s

ORKÖY GENEL MÜDÜRLÜĞÜ, (2002). Türkiye'de ormancılık ve kooperatif ilişkilerinde durum değerlendirmesi, 1. Ulusal Ormancılık Kooperatifleri Sempozyumu Bildiri Kitabı, Kastamonu, s.15-34.

Önal, P. (2010). Orman köylerinde ORKÖY tarafindan gerçekleştirilen köy kalkındırma projelerinin uygulama sonuçlarının araştırılmasi (Şile-İstanbul), İstanbul Üniversitesi, Fen Bilimleri Enstitüsü, Yüksek Lisans Tezi, İstanbul, $159 \mathrm{~s}$

Özsan, M. (2011). Beypazarı orman köylerinde kırsal kalkınma araştırmaları, Kahramanmaraş Sütçü İmam Üniversitesi, Fen Bilimleri Enstitüsü, Yüksek Lisans Tezi, Kahramanmaraş, 141 s.

Solmaz, E., 2007. Muğla orman köylerinin kalkınmasına yönelik uygulanan politikaların yoksulluk düzeyi ve orman kaynaklarının kullanımına etkisi-Muğla örneği, Muğla Üniv. Sosyal Bilimler Enstitüsü İktisat Anabilim Dalı, Doktora Tezi.

Soydan, G. (2010). Adana ilinde orman köylerinin kalkındırılmasına yönelik olarak ORKÖY kredileri uygulaması üzerine bir araştırma, Çukurova Üniversitesi, Fen Bilimleri Enstitüsü, Yüksek Lisans Tezi, Adana, 66 s

Toksoy, D., Bayramoğlu, M.M. (2017). Kırsal kalkınma ve orman köyleri, Karadeniz Teknik Üniversitesi Orman Fakültesi, Genel Yayın No:244, Fakülte Yayın No:42, Trabzon.

Tonyalı, S.A. (2019). Orman köylülerinin güneş enerjili su ısıtma sistemlerini kullanmasıyla ortaya çıkan sosyo ekonomik durumun değerlendirilmesi Gümüşhane Örneği, Gümüşhane Üniversitesi, Fen Bilimleri Enstitüsü, Yüksek Lisans Tezi, Gümüşhane, $60 \mathrm{~s}$

TÜİK, (2013). ADNSK 2013, http://tuikapp.tuik.gov.tr/ADNSK 2013 Sonuç (Erişim tarihi:15.12.2020)

Türkiye Ormancılar Derneği, (2019). Türkiye ormancılığı: 2019. TOD Yayın No:47. Ankara.

Usta, O. (2020). Orman köylüsünün ormancılık kooperatifleri hakkındaki düşünceleri (Artvin İli Örneği), Artvin Çoruh Üniversitesi, Fen Bilimleri Enstitüsü, Yüksek Lisans Tezi, Artvin, 52 s

Uzun, Ş. (2010). Bartın orman işletme müdürlüğü Amasra orman işletme şefliği bünyesinde orman-halkormancılık etkileşimleri, Bartın üniversitesi, Fen Bilimleri Enstitüsü, Yüksek Lisans Tezi, Bartın, 93 s

Vedeld, P., Angelsen, A., Bojö, J., Sjaastad, E., Berg, G.K. (2007). Forest environmental incomes and the rural poor, Forest Policy and Economics, (9), s.869-879. 